\title{
Removal of Ni (II) Ions on to Polymer Loaded Sawdust (PLSD) - Batch Adsorption Studies
}

Tajun Meera Begum KM${ }^{1}$, Alhaji NMI ${ }^{2 *}$, Ayeshamariam A $^{3}$, Vidhya VS ${ }^{4}$ and Jayachandran $\mathbf{M}^{5}$

${ }^{1}$ Arignar Anna Government Arts and Science College, Karaikal 609605, Puducherry, India

${ }^{2}$ Department of Chemistry, Khadir Mohideen College, Adirampattinam 614701, Tamilnadu, India,

${ }^{3}$ Department of Physics, Khadir Mohideen College, Adirampattinam, 614701, Tamilnadu, India

${ }^{4}$ Department of Chemistry, Chenthuran College of Engineering and Technology, Pudukkottai, Tamilnadu, India

${ }^{5}$ Department of Physics, Sree Sevugan Annamalai College, Devakottai, 630303, India

\begin{abstract}
Heavy metal ions are intensively polluting water is a major environmental problem and removal of those ions is highly important because of their toxic nature. In this present study, carbonized sawdust was impregnated with poly (sodium 4-styrene sulphonate) (PSSS) to enhance the metal affinity and selectivity via surface chelating ion-exchange as well as hydrogen bonding adsorption mechanism. An adsorbent characteristic was analyzed through Scanning Electron Microscopy (SEM), Fourier Transform Infrared Spectroscopy (FTIR) and BET analysis. The process variables such as feed concentration, agitation speed, temperature effect and $\mathrm{pH}$ of the solution were optimized by adsorption studies for the analysis of $\mathrm{Ni}$ (II) ions removal. Various isotherm models were fixed with experimental data to explain the interaction of solute with adsorbent in batch studies. Kinetic behavior of different kinetic models and thermodynamic properties was also determined. The best isotherm in this study was selected by error analysis ( $X 2$ test) and the stability of adsorbents was also confirmed through desorption studies.
\end{abstract}

Keywords: Sawdust carbon; Polymer-ionomer; Morphology of adsorbent; Nickel (II); Ions and adsorption

\section{Introduction}

Due to heaviness, bio-accumulating tendency and toxicity, heavy metal ions is contaminated water by industrial wastes is causes severe health defects to human life. Among various harmful industrial pollutants, pollution by heavy metal is the major problem. Nickel is one of the heavy metal and its exposure at higher concentration causes lungs cancer, nose and bone cancer, gastrointestinal distress, dermatitis etc. [1]. The main sources of heavy metals are mining and industrial wastes such as vehicle emission, batteries, fertilizers, metal finishing, paints, forging and treated woods, its concentration from these industries varies between 6 and $12 \mathrm{mg} / \mathrm{L}$. The tolerable limit of Ni presence in drinking water level is $0.01 \mathrm{mg} / \mathrm{L}$ and the industrial discharge limit in wastewater is $2 \mathrm{mg} / \mathrm{g}$ reported by Worlds Health Organization (WHO) [2]. Agricultural and marine waste materials are converting into adsorbents was mainly concentrated from the past decade. Among those, sawdust and chitosan are the most promising adsorbent for removing these heavy metals from water and wastewater. Sawdust is one of the cheapest biomass having the constituents of cellulose (55$60 \%)$, hemicelluloses (20-25\%), lignin (20-25\%). The functional groups present in sawdust molecules are such as acetamido groups, phenol, carbonyl, sulphydryl carboxyl groups, structural polysaccharides, amido groups, amino groups, esters and alcohols and these groups have the metal complexation affinity [3,4]. Different research workers have been reported the complexation behavior of various functional groups present in heavy metals during biosorption process using spectroscopic techniques. To enhance the capability and efficiency, pretreatment and surface modifications may be needed [5].

Due to its high surface area and easy availability, activated carbon is widely used as an adsorbent. Removal of $\mathrm{Ni}$ (II) ions from water and effluents using different forms of activated carbons as adsorbent are reported [6-10]. In recent years, several non-conventional and less expensive adsorbents are used for the removal of $\mathrm{Ni}$ (II) ions such as sphagnum peat, blast furnace slag, apple waste, soybean and cottonseed husk, peat nut husk carbon, straw, rice husk, treated saw dust and activated alumina and silica gel [11-18]. Activated carbons are treated with acid, bases and oxidizing agents to enhance their surface activity. Enhancement of binding ability of the sawdust is modified with some other materials, such as dyestuff, hexamine, polyacrylamide, crosslinked polyethylenimine or other chemicals to introduce more extra active sites like -N, -S, and -P [19].

For example, divalent ions were effectively removed from an aqueous solution by using polysulfide treated sawdust have been reported. Surface modification of carbonized sawdust by impregnation of chelating polymer improves the metal affinity and selectivity for the adsorption of heavy metal through complexation mechanism. Poly-(Sodium 4-Styrene Sulphonate (PSSS) is one of the metalchelating biocompatible polymers. Polystyrene sulfonates polymers are combined structured of polystyrene and sulfonic acid or sulfonate functional groups. Polystyrene sulfonates are linear polymer, water soluble and white in colour when very pure. The cross-linked material (called a resin) typically appears amber in color because the sulfonic acid group $\left(-\mathrm{SO}_{3} \mathrm{H}\right)$ is strongly acidic, this polymer neutralizes bases and produce various salts leading to $\mathrm{Na}$ and $\mathrm{Ca}$.

$$
\left(\mathrm{CH}_{2} \mathrm{CHC}_{6} \mathrm{H}_{4} \mathrm{SO}_{3} \mathrm{H}\right)_{n}+\mathrm{n} \mathrm{NaOH} \rightarrow\left(\mathrm{CH}_{2} \mathrm{CHC}_{6} \mathrm{H}_{4} \mathrm{SO}_{3} \mathrm{Na}\right)_{n}+\mathrm{n} \mathrm{H}_{2} \mathrm{O} \text { (1) }
$$

These ion-containing polymers are called PSSS are widely used to remove ions from a solution in technical and medical applications [20]. PSSS is used to indicate potassium binders in acute and chronic

*Corresponding author: Alhaji NMI, Department of Chemistry, Khadir Mohideen College, Adirampattinam 614701, Tamilnadu, India, E-mail: nmialhaji@gmail.com; mjayam54@yahoo.com

Received September 25, 2016; Accepted October 23, 2016; Published October 30, 2016

Citation: Tajun Meera Begum KM, Alhaji NMI, Ayeshamariam A, Vidhya VS, Jayachandran M (2016) Removal of Ni (II) lons on to Polymer Loaded Sawdust (PLSD)-Batch Adsorption Studies. Fluid Mech Open Acc 3: 138. doi: 10.4172/24762296.1000138

Copyright: (C) 2016 Tajun Meera Begum KM, et al. This is an open-access article distributed under the terms of the Creative Commons Attribution License, which permits unrestricted use, distribution, and reproduction in any medium, provided the original author and source are credited. 
Citation: Tajun Meera Begum KM, Alhaji NMI, Ayeshamariam A, Vidhya VS, Jayachandran M (2016) Removal of Ni (II) lons on to Polymer Loaded Sawdust (PLSD)-Batch Adsorption Studies. Fluid Mech Open Acc 3: 138. doi: 10.4172/2476-2296.1000138

Page 2 of 6

kidney disease for patients suffering from hyperkalaemia (high blood serum potassium levels), which may result in weakness irregular heartbeat. Hence this present paper is intend the preparation and characterization of PSSS polymer impregnated carbonized sawdust which was used as an economic viable modified adsorbent, Polymer Loaded Saw Dust (PLSD) for the removal of $\mathrm{Ni}$ (II) ions from aqueous solutions. Adsorption isotherms and kinetic behavior analysis were studied to explain the solute interaction mechanism and predict the thermodynamic properties of adsorption process to assess the spontaneous nature. $\chi^{2}$ Test statistics were used for the determination of best-fitting isotherm with the experimental data. Retaining of metal ions in non-labile forms is shown in regeneration studies.

\section{Materials and Methods}

\section{Materials}

Sawdust was purchased from the local saw mill. The polymer, Poly Sodium 4-Styrene Sulphonate (PSSS) was used for impregnation. Ni (II) stock solution was prepared by using Nickel sulphate hexahydrate and double distilled water. Addition of $\mathrm{HCl}$ and $\mathrm{NaOH}$ is maintained the $\mathrm{pH}$ level of the solution. Analytical grade reagents of dimethyl glyoxime, ammonium solution were used for analyzing the $\mathrm{Ni}$ (II) ions.

Preparation of polymer impregnated carbonized sawdust: A procedure similar to that followed for the preparation of sawdust chitosan composite beads [21] was followed. Sawdust was sieved by sieve plate to obtain the uniform size $(0.5 \mathrm{~mm})$ of particles and was treated with concentrated sulphuric acid $(50 \mathrm{~mL}$ per $10 \mathrm{~g})$ for $2 \mathrm{~h}$ to get carbonized sawdust powder And then treated with sodium carbonate $(0.1 \mathrm{~N})$ for neutralization till the effervescence stops and dried again in hot air oven at $100^{\circ} \mathrm{C}$. The product obtained after carbonization was treated with $60 \%$ PSSS $(1: 1 \% \mathrm{wt} / \mathrm{v}$ of carbonized sawdust and PSSS stirred at room temperature in a rotary shaker for about $24 \mathrm{~h}$ at $200 \mathrm{rpm}$. Then, the mixture was washed thoroughly using distilled water until the $\mathrm{pH}$ of rinsed water was found to be neutral. Finally the samples were dried in a hot air oven at $100^{\circ} \mathrm{C}$.

Characterization of adsorbents: Carbonized materials were analyzed by using GeminiV2.00 Micromeritics to determine the specific surface area. Hitachi S3000H Scanning Electron Microscope was used for analyze the surface morphological structure. Functional groups analysis was carried out using Perkin Elmer spectrum RXI FTIR spectrophotometer.

Batch Adsorption: To determine the equilibrium time and agitation speed for a known concentration of initial metal ion solution through adsorption studies. Batch adsorption studies were carried out to investigate the effect of initial metal ion concentration, adsorption dosage and $\mathrm{pH}$ of the solution at equilibrium time and agitation speed in rotary shaker. Whatmann filter paper was used for the filtration of supernatant and the concentrations of $\mathrm{Ni}$ (II) ions were determined using UV/visible spectrophotometer at a wavelength of $440 \mathrm{~nm}$. The adsorption capacity $\left(\mathrm{q}_{\mathrm{e}} \mathrm{mg} / \mathrm{g}\right)$ and \% removal were calculated using Equations (2) and (3), respectively.

$$
\mathrm{q}_{\mathrm{e}}=\frac{\left(\mathrm{C}_{\mathrm{o}}-\mathrm{C}_{\mathrm{e}}\right) \mathrm{V}}{\mathrm{W}}
$$

Percentage Removal $=\left(\frac{\left(\mathrm{C}_{\mathrm{o}}-\mathrm{C}_{\mathrm{e}}\right)}{\mathrm{C}_{\mathrm{o}}}\right) \times 100$

Where $\mathrm{C}_{\mathrm{o}}$ : Concentration of $\mathrm{Ni}$ (II) ion at initial (mg/L)

$\mathrm{C}_{\mathrm{e}}$ : Concentration of $\mathrm{Ni}(\mathrm{II})$ ion at any instant $(\mathrm{mg} / \mathrm{L})$
V: Volume of the solution (L)

$\mathrm{W}$ : Mass of adsorbent ( $\mathrm{g}$ )

\section{Results and Discussion}

The characterization of polymer treated carbonized sawdust is given in detail as follows.

\section{BET Analysis}

The specific surface area of untreated and polymer treated carbonized sawdust were found to be $13.6 \mathrm{~m}^{2} / \mathrm{g}$ and $114.3 \mathrm{~m}^{2} / \mathrm{g}$, respectively. The increase in the surface area of polymer treated carbonized sawdust is due to the well impregnation of polymer into carbonized sawdust.

\section{SEM analysis and FTIR spectrum}

According to the image, sawdust particles were homogeneously dispersed and good adhesion between the particles and polymer matrix was evident. This is due to the presence of the hydrophilic, hydroxyl on the surface of lingo-cellulosic which resulted with aggregation of polymer matrix [22]. So this Morphological study shows better interfacial bonding between fiber and matrix. The image exhibits roughness, more crisp, cracked and many pores were clearly found on the surface (Table 1).

This table and FTIR spectrum show the presence of surface polar functional group such as amino, carbonyl, hydroxyl, aliphatic $\mathrm{C}-\mathrm{H}$, conjugated $\mathrm{C}=\mathrm{C}, \mathrm{C}-\mathrm{N}$, asymmetric $-\mathrm{SO}_{3}$, etc. The shifts in the position of peaks before and after $\mathrm{Ni}$ (II) ions loading indicates that metal ion well associated with the binding centers of atom containing $\mathrm{O}, \mathrm{N}, \mathrm{S}$ and aromatic ring, etc [23-25]. The anionic surface modifications of PLSD is indicated by the observed change in position of peaks of asymmetric sulphites (ie., from $1197.21 \mathrm{~cm}^{-1}$ to $1207.53 \mathrm{~cm}^{-1}$ ), conjugated $\mathrm{C}=\mathrm{C}$ in benzene (ie., from $1613.48 \mathrm{~cm}^{-1}$ to $1712.60 \mathrm{~cm}^{-1}$ ) and $(\mathrm{C}=\mathrm{S})$ stretching (ie., from $1028 \mathrm{~cm}^{-1}$ to $1034 \mathrm{~cm}^{-1}$ ). Stretching and bending frequencies are responsible for the incorporation of heteroatom in activated carbon matrix (PLSD) (Figures 1 and 2).

\section{Effect of variables}

Determination on the effect of $\mathrm{pH}$, initial metal ion concentration, contact time and agitation speed on adsorption capacity of PLSD for the removal of $\mathrm{Ni}$ (II) ions from aqueous solution were analyzed by Batch adsorption studies and the results are illustrated in (Figures 3-6) respectively.

At $\mathrm{pH}=5$, the sorption capacity is more and $\mathrm{Ni}$ (II) ions exist as $\mathrm{Ni}^{2+}, \mathrm{Ni}(\mathrm{OH})^{+}, \mathrm{Ni}(\mathrm{OH})_{2}$. In adsorption process, the initial $\mathrm{Ni}$ (II) ions concentration acts as a driving force to overcome the mass transfer

\begin{tabular}{|l|l|l|}
\hline Functional groups & PLSD & $\begin{array}{l}\text { Ni- loaded } \\
\text { PLSD }\end{array}$ \\
\hline O-H (H bonded)and NH stretching & $3412.95 \mathrm{~cm}^{-1}$ & $3364.37 \mathrm{~cm}^{-1}$ \\
\hline Aliphatic C-H stretching and N-H stretching & $2923.51 \mathrm{~cm}^{-1}$ & $2930.13 \mathrm{~cm}^{-1}$ \\
\hline O-H \& S-H stretching in acid group & $2358.04 \mathrm{~cm}^{-1}$ & $2360.17 \mathrm{~cm}^{-1}$ \\
\hline Conjugated C=C in benzene\& N-Hbending in amine & $1613.48 \mathrm{~cm}^{-1}$ & $1712.60 \mathrm{~cm}^{-1}$ \\
\hline C-N stretching(or)asymmetric-SO3 group & & \\
\hline (C-O), (C=S)stretching, O-H bending & $1197.21 \mathrm{~cm}^{-1}$ & $1207.53 \mathrm{~cm}^{-1}$ \\
\hline Aromatic ring & $1027.67 \mathrm{~cm}^{-1}$ & $1034.87 \mathrm{~cm}^{-1}$ \\
\hline Wagging of $-\mathrm{NH}$ & $669.62 \mathrm{~cm}^{-1}$ & $798.68 \mathrm{~cm}^{-1}$ \\
\hline & $537.72 \mathrm{~cm}^{-1}$ & $638.25 \mathrm{~cm}^{-1}$ \\
\hline
\end{tabular}

Table 1: Functional groups present in PLSD and Ni-loaded PLSD using FT-IR spectra. 
Citation: Tajun Meera Begum KM, Alhaji NMI, Ayeshamariam A, Vidhya VS, Jayachandran M (2016) Removal of Ni (II) lons on to Polymer Loaded Sawdust (PLSD)-Batch Adsorption Studies. Fluid Mech Open Acc 3: 138. doi: 10.4172/2476-2296.1000138

Page 3 of 6

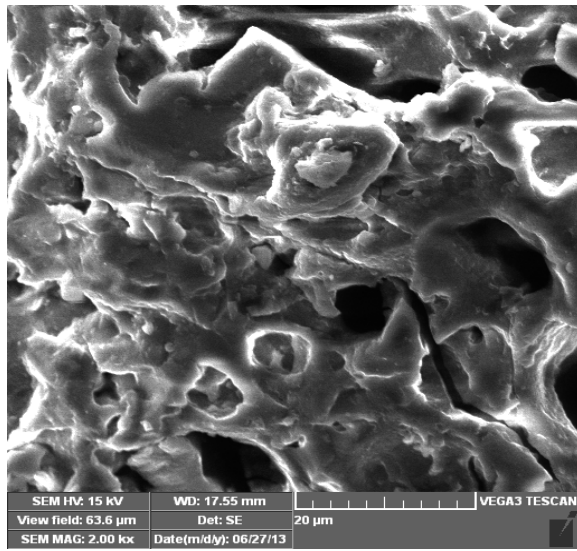

Figure 1: SEM image of PLSD

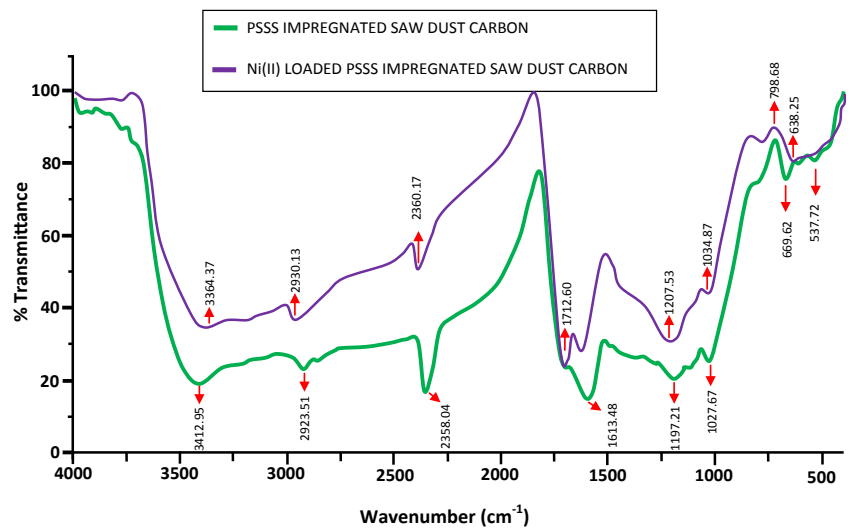

Figure 2: FTIR spectra of PLSD before and after loading of Ni (II) ions.

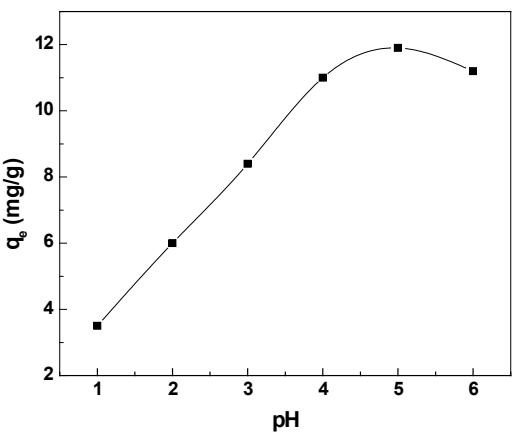

Figure 3: Effect of $\mathrm{pH}$.

between the adsorbent and adsorbate. At $\mathrm{pH}=5$, ionic and non-ionic active species of adsorbate may be adsorbed on the anionic surface with the formation of surface ion-exchange as well as hydrogen bonding ion pair complex between electron donating sites of PLSD and electron deficient nickel ions. The favorable removal of $\mathrm{Ni}$ (II) at higher $\mathrm{pH}$ is related with increasing negative charge density onto PLSD [19]. In the present study, the adsorption capacity increases from $2.5 \mathrm{mg} / \mathrm{g}$ to $43.7 \mathrm{mg} / \mathrm{g}$ and percentage removal decreases from $98.8 \%$ to $58.2 \%$ in the initial concentration ranging from $10 \mathrm{ppm}$ to $300 \mathrm{ppm}$ with same contact time and adsorption temperature (Figure 4).
The rate of adsorption initially increases and then gradually remains constant with increase in contact time and the equilibrium is reached nearly at $180 \mathrm{~min}$ for PLSD is shown in (Figure 5). At the initial stage, more number of surface sites is available for the adsorption and after a lapse of time, the occupation of remaining surface sites are difficult due to the repulsion between the solid and bulk phases of solute molecules $[17,18]$. Adsorption of $\mathrm{Ni}$ (II) ion is required $180 \mathrm{~min}$ to attain equilibrium. The equilibrium period does not change with the change of initial concentration of the metal ion solution is observed from the figure.

Figure 6 establishes that the rate of adsorption increases with agitation speed. The maximum $94 \%$ sorption is obtained at $200 \mathrm{rpm}$ beyond which the increase is not significant. This is happened because of proper contact between the metal ion and active site is developed when increasing the agitation speed. Thus increase of the agitation speed improves the diffusion of Nickel ions towards the surface of the adsorbents. Hence the equilibrium agitation speed was fixed at $200 \mathrm{rpm}$.

The adsorption capacity of $\mathrm{Ni}$ (II) ions onto PLSD was determined at different temperatures and the results show that the uptake of $\mathrm{Ni}$ (II) ions onto PLSD increases with increasing temperature, implying that the adsorption capacity largely depend on the indirect interaction between the functional groups on the PLSD surface and adsorbate [26,27]. The increase in adsorption capacity may be due to the formation of some new adsorption sites, the enlargement of the pores during surface modification of adsorbent and also the significant role of increased rate

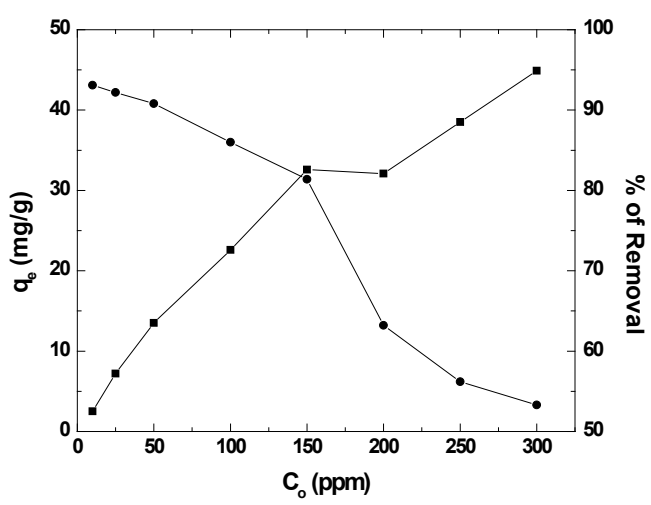

Figure 4: Effect of initial metal ion concentration.

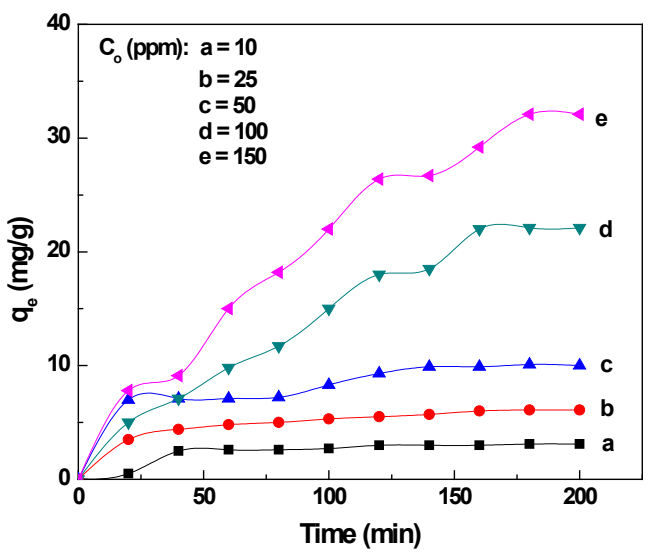

Figure 5: Effect of contact time. 
Citation: Tajun Meera Begum KM, Alhaji NMI, Ayeshamariam A, Vidhya VS, Jayachandran M (2016) Removal of Ni (II) lons on to Polymer Loaded Sawdust (PLSD)-Batch Adsorption Studies. Fluid Mech Open Acc 3: 138. doi: 10.4172/2476-2296.1000138

Page 4 of 6

of intraparticle diffusion in the initial stage of adsorption into the pores at higher temperature leading to the endothermic adsorption. The results are compiled in (Table 2).

The $\Delta \mathrm{G}^{\circ}, \Delta \mathrm{H}^{\circ}$ and $\Delta \mathrm{S}^{\circ}$ values calculated at $303 \mathrm{~K}$ are $-2.70 \mathrm{~kJ} /$ $\mathrm{mol}, 31.87 \mathrm{~kJ} / \mathrm{mol}$ and $114.2 \mathrm{~J} / \mathrm{K} / \mathrm{mol}$, respectively and the energy of activation $\left(\mathrm{Ea}=\Delta \mathrm{H}^{\circ}+\mathrm{RT}\right)$ is $34.39 \mathrm{~kJ} / \mathrm{mol}$. These thermodynamic parameters can be explained the interaction nature of the absorbentadsorbate. If the Ea value less than $+42 \mathrm{~kJ} / \mathrm{mol}$ points out that the adsorption process here is not a chemically-controlled one. $\Delta \mathrm{G}^{\circ}$ varies from $-2.70 \mathrm{~kJ} / \mathrm{mol}$ to $-7.20 \mathrm{~kJ} / \mathrm{mol}$ with temperature ranging from $303 \mathrm{~K}$ to $343 \mathrm{~K}$, implying that $\Delta \mathrm{G}^{\circ}$ becomes more negative at higher temperatures. The negative $\Delta \mathrm{G}^{\circ}$ and positive $\Delta \mathrm{H}^{\circ}$ and $\Delta \mathrm{S}^{\circ}$ indicate that this is a feasible, spontaneous, endothermic, increased randomness of heterogeneous adsorption through physical phenomena.

\section{Adsorption isotherm}

The interaction of solute in the liquid phase and the adsorbent in solid phase is illustrated by adsorption isotherm. So many models of analyzing adsorption isotherm behavior [28] are available to fit the experimental data. Using Langmuir, Freundlich, Temkin and DubininRadushkevich (D-R) adsorption isotherm models for quantify the adsorption capacity of adsorbents for the adsorption of Ni (II) from aqueous solution. Langmuir isotherm indicates surface homogeneity and monolayer adsorption by the separation factor, $\mathrm{R}_{\mathrm{L}}$ which is between 0 and 1 for favorable adsorption. Surface heterogeneity and multilayer sorption determined by Freundlich isotherm. Temkin model considers the effects of adsorbent-adsorbate interaction. Dubinin-Radushkevich (D-R) Model is used to determine the adsorption occurred is physical or chemical in nature. The adsorption potential $(\varepsilon)$ is depends on the nature of the adsorbent and adsorbate but independent of the temperature. The mean free energy of the adsorption $\mathrm{E}$, which is the free energy for the transfer of one mole of metal ions from the infinity to the surface of the adsorbent, provide information about the nature

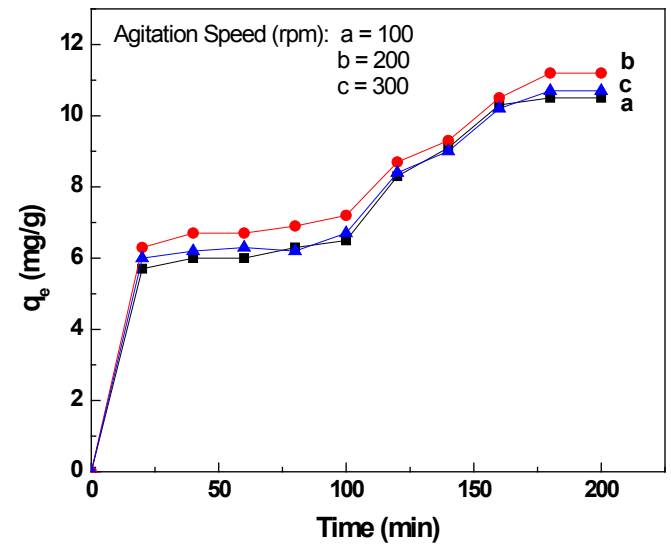

Figure 6: Effect of agitation speed.

\begin{tabular}{|c|c|c|c|c|c|c|}
\hline $\mathbf{T}, \mathbf{K}$ & $\begin{array}{c}\Delta \mathbf{G}^{\circ} \\
\mathbf{k J} / \mathbf{m o l}\end{array}$ & $\begin{array}{c}\Delta \mathbf{H}^{0} \\
\mathbf{k J / m o l}\end{array}$ & $\begin{array}{c}\Delta \mathbf{S}^{0} \\
\mathbf{J} / \mathbf{K} \cdot \mathbf{m o l}\end{array}$ & $\begin{array}{c}\mathbf{T} \Delta \mathbf{S}^{0} \\
\mathbf{k J} / \mathbf{m o l}\end{array}$ & $\begin{array}{c}\mathbf{E a} \\
\mathbf{k J} / \mathbf{m o l}\end{array}$ & $\mathbf{R}^{\mathbf{2}}$ \\
\hline 303 & -2.70 & $31.87 \pm 1.27$ & $114.2 \pm 4.0$ & 34.59 & 34.39 & 0.990 \\
\hline 313 & -3.90 & & & 35.73 & & \\
\hline 323 & -4.88 & & & 36.87 & & \\
\hline 333 & -6.30 & & & 38.01 & & \\
\hline 343 & -7.20 & & & 39.15 & & \\
\hline
\end{tabular}

Table 2: Activation parameters for Ni (II) adsorption on PLSD. of adsorption either chemical ion exchange or physical ion exchange adsorption. The values of $\mathrm{E}$ lies between 8 and $16 \mathrm{~kJ} / \mathrm{mol}$ depicts the adsorption process follows the chemical ion-exchange and if $\mathrm{E}<8 \mathrm{~kJ} /$ mol, the adsorption process is of a physical ion-exchange via weak electrostatic nature $[29,30]$. The linearized form of these isotherms were applied to the adsorption of $\mathrm{Ni}$ (II) on to PLSD and the constants obtained from the slope and intercept of the plots have been compiled in Table 2.

\section{Selection by error analysis}

The linear regression and the non-linear $\chi^{2}$ analysis gave different models as the best-fitting isotherm for the given data set, thus indicating a significant difference between the analytical methods. Non-linear $\chi^{2}$ test provided a better determination for the experimental data [31]. In this analysis, correlation coefficient $\left(\mathrm{r}^{2}\right)$ and $\chi^{2}$ test statistics were used for the determination of best-fitting isotherm with the experimental data.

The mathematical derivation was given by the equation (4).

$$
x^{2}=\sum \frac{\left(q_{e}-q_{e, m}\right)^{2}}{q_{e, m}}
$$

where, $q_{e, m}$ : equilibrium capacity $(\mathrm{mg} / \mathrm{g})$ calculated from model

$q_{e}$ : equilibrium capacity $(\mathrm{mg} / \mathrm{g})$ calculated from experimental data.

$\chi^{2}$ Would be a small number and vice versa when the data from model are similar to the experimental data [31]. In linear analysis, the regression coefficient $(r)$ and coefficient of determination $\left(r^{2}\right)$ value will affect significantly of the final determination. It can be avoided by using nonlinear chi square test analysis.

Figure 7 shows the equilibrium adsorption of $\mathrm{Ni}$ (II) ions onto PLSD and the isotherms are plotted together with the experimental data. Both Temkin and Freundlich models show good fit with the experimental data. But Temkin has the lowest chi-square value $(=3.14)$ and moderately high $\mathrm{r}^{2}(=0.941)$ which indicates the favorable indirect interaction (larger B value) between ions and solid surface. Even though the Langmuir has the highest $\mathrm{r}^{2}(=0.982)$ and chi-square value $(=58.64)$ suggests that the adsorption is not homogeneous. Similar contradict observations were reported [32]. Chatterjee et al., (2009) through the application of correlation coefficients $\left(\mathrm{r}^{2}\right)$ and $\chi^{2}$ error analysis. The mean free energy for adsorption $(=1.39 \mathrm{~kJ} / \mathrm{mol})$ through DRK isotherm justifies weak forces are used in this ion-exchange adsorption. (if $\mathrm{E}$ is less than $8 \mathrm{~kJ} / \mathrm{mol}$ the process is of physical nature.) So Temkin

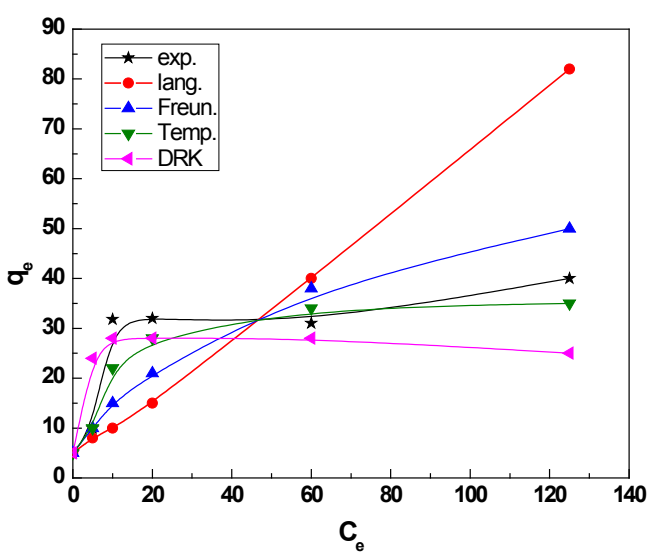

Figure 7: Selection of isotherm (PLSD-Ni). 
Citation: Tajun Meera Begum KM, Alhaji NMI, Ayeshamariam A, Vidhya VS, Jayachandran M (2016) Removal of Ni (II) lons on to Polymer Loaded Sawdust (PLSD)-Batch Adsorption Studies. Fluid Mech Open Acc 3: 138. doi: 10.4172/2476-2296.1000138

Page 5 of 6

\begin{tabular}{|c|c|c|c|c|c|}
\hline S. No. & Isotherm Model & Equation & Constants for PLSD & $\mathbf{r}^{2}$ & $x^{2}$ \\
\hline 1 & Langmuir & $\begin{array}{l}C_{e} / q_{e}=1 / b \cdot \theta+C_{e} / \theta \\
K_{L}=(\theta \cdot b) \\
R_{L}=1 /\left(1+b C_{0}\right) \\
\left.\text { (i.e. } C_{0}=50 p p m\right)\end{array}$ & $\begin{array}{l}\theta=44.1 \mathrm{mg} / \mathrm{g} \\
\mathrm{b}=0.144 \mathrm{Lmg}^{-1} \\
\mathrm{~K}_{\mathrm{L}}=6.34 \mathrm{Lg}^{-1} \\
\mathrm{R}_{\mathrm{L}}=0.122\end{array}$ & 0.982 & 58.64 \\
\hline 2 & Freundlich & $\ln q_{e}=\ln K_{F+} 1 / n \ln C_{e}$ & $\begin{array}{l}n=2.42 \\
k_{F}=7.33 \mathrm{~L} \mathrm{~g}^{-1}\end{array}$ & 0.960 & 5.7 \\
\hline 3 & Temkin & $\mathrm{q}_{\mathrm{t}}=\mathrm{B} \ln \mathrm{K}_{\mathrm{T}}+\mathrm{B} \ln \mathrm{C}_{\mathrm{e}}$ & $\begin{array}{l}\mathrm{B}=6.042 \\
\mathrm{~K}_{\mathrm{T}}=6.25 \mathrm{~L} \mathrm{~g}^{-1}\end{array}$ & 0.941 & 3.14 \\
\hline 4 & $\begin{array}{l}\text { Dubinin-Radushkevich } \\
\text { isotherm }\end{array}$ & $\begin{array}{l}\text { In } q e=\ln q_{m}-k \varepsilon 2 \\
\varepsilon=R T \ln (1+1 / C e) \\
E=\left(2 k^{\prime)-0.5}\right.\end{array}$ & $\begin{array}{l}\mathrm{q}_{\mathrm{m}}=27.58 \mathrm{mg} / \mathrm{g} \\
\mathrm{K}=0.258 \mathrm{~mole} \mathrm{e}^{2 / \mathrm{J}^{2}} \\
\mathrm{E}=1.39 \mathrm{~kJ} / \mathrm{mol}\end{array}$ & 0.715 & 18.26 \\
\hline
\end{tabular}

Table 3: Summary of parameters for various isotherm models

\begin{tabular}{|c|c|c|c|}
\hline S. No. & Kinetic model & Linear equation & Constant for PLSD (50 ppm) \\
\hline 1 & $\begin{array}{l}\text { Pseudo } \\
\text { first order }\end{array}$ & $\ln \left(q_{e}-q_{t}\right)=\ln q_{e}-k_{1} t$ & $\begin{array}{l}\mathrm{k}_{1}=1.34 \pm 0.22 \times 10^{-2} \mathrm{~min} \\
\mathrm{R}^{2}=0.863\end{array}$ \\
\hline 2 & $\begin{array}{l}\text { Pseudo } \\
\text { second order }\end{array}$ & $\begin{array}{l}t / q_{t}=1 / k_{2} q_{e}^{2+t} t / q_{e} \\
h=k_{2} q_{e}^{2}\end{array}$ & $\begin{array}{l}\mathrm{q}_{\mathrm{e}}=14.1 \pm 1.2 \mathrm{mg} / \mathrm{g} \\
\mathrm{k}_{2}=1.50 \pm 0.05 \times 10^{-3} \mathrm{~g} / \mathrm{mg} \cdot \mathrm{min} \\
\mathrm{h}=2.98 \mathrm{mg} / \mathrm{g} \cdot \mathrm{min} ; \\
\mathrm{R}^{2}=0.951\end{array}$ \\
\hline 3 & Simple Elovich & $q_{t}=\beta \ln _{t+} \beta \ln (\alpha \beta)$ & $\begin{array}{l}\alpha=0.17 \mathrm{mg} / \mathrm{g} \cdot \mathrm{min} \\
\beta=2.52 \mathrm{~g} / \mathrm{mg} \\
\mathrm{R}^{2}=0.844\end{array}$ \\
\hline 4 & $\begin{array}{l}\text { Intra } \\
\text { particle diffusion }\end{array}$ & $q_{t}=k_{i d} \cdot t^{0.5}+c$ & $\begin{array}{l}\mathrm{k}_{\mathrm{id}}, 1=0.34 \mathrm{mg} / \mathrm{g} \mathrm{min} 0.5 \\
\mathrm{C}_{1}=4.931 \mathrm{mg} / \mathrm{g} \\
\mathrm{R}^{2}=0.924 \\
\mathrm{k}_{\text {id }}, 2=0.748 \mathrm{mg} / \mathrm{g} \mathrm{min} \\
\mathrm{C}_{2}=1.529 \mathrm{mg} / \mathrm{g} \\
\mathrm{R}^{2}=0.948\end{array}$ \\
\hline
\end{tabular}

Table 4: Summary of parameters for various kinetic models

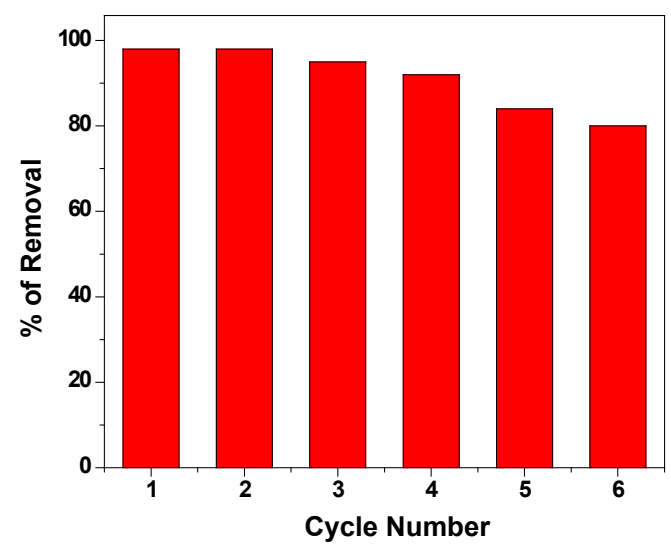

Figure 8: Reusability of PLSD for the adsorption of $\mathrm{Ni}$ (II) ions.

model shows a good fit with the experimental data and the values of the heterogeneity factor $(n>1)$ indicates the heterogeneous adsorption through physical phenomena.

\section{Adsorption kinetics}

Kinetic data showed better fit of pseudo second order but the rate is also influenced by intra particle diffusion [33]. But the gradual intra particle diffusion stage is not the rate controlling step, since the line does not pass through origin. The multi-linearity plot of intra particle diffusion model explained the initial linear portion indicates the boundary layer diffusion effects and the final linear portion is the result of intra particle diffusion effects. This can be attributed to the instantaneous utilization of the most readily available sites on the PLSD. The boundary layer thickness values indicate that the larger intercept and greater boundary layer effect. So, the intra particle diffusion played significant role at the initial stage of adsorption process [34]. The Pseudo second order model indicates rapid adsorption initially due to ion-exchange and followed by slower adsorption because of diffusion of ions into pores for longer duration. The better-fit of intra particle diffusion method rather than simple Elovich indicates that the significance of acid-base as well as ion-pair sorption occurs between the Nickel ions and activation sites of PLSD.

\section{Adsorption mechanism}

The adsorption of Ni (II) ions onto PLSD occurs as multistep process [19] involving (i) Initially ion-exchange rapidly because of weak electrostatic force of attraction between solid-solute interfaces and (ii) diffusion of ions then into the pores slowly by endothermic chemisorptions with active sites of adsorbent. So this chemisorption mechanism is evidenced by pseudo second order kinetics, intra particle diffusion and activation parameters. Finally the equilibrium is reached due to bonding with binding centers of surface functionality of the surface modified carbonized sawdust (PLSD). (5-7):

The adsorption mechanisms are shown in the following equations

\section{For Ni (II) ions: (Ion exchange)}

$$
\begin{aligned}
& 2\left(\mathrm{Ar}-\mathrm{Y}^{-}-\mathrm{C}-\mathrm{X}^{+}\right)+\mathrm{Ni}^{2+} \rightarrow\left(\mathrm{Ar}-\mathrm{C}-\mathrm{X}^{+}\right)_{2} \mathrm{Ni} \\
& \left(\mathrm{Ar}-\mathrm{Y}^{-}-\mathrm{C}-\mathrm{X}^{+}\right)+\mathrm{Ni}(\mathrm{OH})^{+} \rightarrow\left(\mathrm{Ar}-\mathrm{Ni}(\mathrm{OH})-\mathrm{C}-\mathrm{X}^{+}\right)
\end{aligned}
$$

\section{(And Hydrogen bonding)}

$$
\left(\mathrm{Ar}-\mathrm{Y}^{-} \mathrm{CX}^{+}\right)+\mathrm{Ni}(\mathrm{OH})_{2} \rightarrow\left(\mathrm{Ar}-\mathrm{Y}^{-}-\mathrm{C}-\mathrm{X}^{+}\right) \mathrm{Ni}(\mathrm{OH})_{2}
$$

Ar is the matrix of the PLSD with $\mathrm{X}^{+} \& \mathrm{Y}^{-}$binding centres such as $-\mathrm{O},-\mathrm{N},-\mathrm{S},(\mathrm{C}-\mathrm{H}),(-\mathrm{C}=\mathrm{C}),(\mathrm{C}-\mathrm{O}),(\mathrm{C}-\mathrm{N})$, etc.

In aqueous solution at $\mathrm{pH} 5$ the active forms of $\mathrm{Ni}$ (II) ions are $\mathrm{Ni}^{2+}$, $\mathrm{Ni}(\mathrm{OH})^{+}, \mathrm{Ni}(\mathrm{OH})_{2}$ [19]. The positive charged active species of metal ions may be heterogeneously adsorbed with the formation of surface ion-exchange complex between electron donating sites of PLSD and electron accepting nature of Nickel ions through physical phenomena. Moreover, the metal ions may be neutral at this high $\mathrm{pH}$ (ie., $\mathrm{Ni}(\mathrm{OH})^{2}$ ) and also be adsorbed by hydrogen bonding mechanism along with ionexchange.

\section{Regeneration studies}

Consecutive adsorption and desorption studies [23] were repeated six times by using the same adsorbent and is shown in Figure which indicate stability of the adsorbent. Metal ions are retained by the matrix in non-labile forms is evident by the multi-linearity plot of intra particle diffusion model and acid-base reactions are more effective for their displacement than complexation processes. 
Citation: Tajun Meera Begum KM, Alhaji NMI, Ayeshamariam A, Vidhya VS, Jayachandran M (2016) Removal of Ni (II) lons on to Polymer Loaded Sawdust (PLSD)-Batch Adsorption Studies. Fluid Mech Open Acc 3: 138. doi: 10.4172/2476-2296.1000138

\section{Conclusion}

In this paper, the PLSD is derived through the impregnation of chelating biocompatible polymer PSSS on agricultural waste product of sawdust. The comparable performance of this low cost bio-sorbent is recommended since PLSD is relatively economically cheap, availability, regenerate, eco-friendly and shows high affinity of $\mathrm{Ni}$ (II) ions (ie.,) $>90 \%$ removal at $\mathrm{pH} 5.0$ evidenced by BET, SEM and FTIR results. Under experimental conditions, the existence of ionic and non-ionic forms of nickel ions $\left(\mathrm{Ni}^{2+}, \mathrm{Ni}(\mathrm{OH})^{+}, \mathrm{Ni}(\mathrm{OH})_{2}\right)$ are well adsorbed by ionexchange as well as hydrogen bonding mechanism with the formation of surface complex. The increase in adsorption capacity may be due to the formation of some new adsorption sites on the surface, the enlargement of the pores on the adsorbent, specific surface area. The intra particle diffusion of $\mathrm{Ni}$ (II) ions into the pores of PLSD leads to the spontaneous endothermic chemisorption which is confirmed by the thermo dynamical parameters and the rate is also influenced by intra particle diffusion. Based on $\mathrm{r}^{2}$ and $\chi^{2}$ equilibrium isotherm for $\mathrm{Ni}$ (II) ions onto PLSD best represented by Temkin isotherm of multilayer ion exchange along with hydrogen bonding sorption via weak electrostatic forces.

\section{References}

1. Kadirvelu K, Tamaraiselvi K, Namasivayam C (2001) Adsorption of Nickel(li) from Aqueous Solution Onto Activated Carbon Prepared From Coirpith. Separation and Purification Technology 24: 497-505.

2. Environmental Pollution Control Alternatives (1990) EPA/625/5-90/25 EPA/625/4-89/23. Environmental Protection Agency, Cincinnati, WHO, USA.

3. Bulut $Y$, Tez $Z$ (2007) Removal of heavy metals from aqueous solution by sawdust adsorption. J Hazard Mat 19: 160- 166.

4. Ansari AK, Mosayebzadeh Z (2010) Removal of basic dye methylene blue from aqueous solutions using sawdust and sawdust coated by polypyrrole. J Iran Chem Soc 7: 339-50.

5. Sud D, Mahajan G, Khaur MP (2008) Agricultural waste material as potential adsorbent for sequestering heavy metal ions from aqueous solutions: A review. Bioresour Technol 99: 6017-6027.

6. Demirbas E, Kobya M, Oncel S, Sencan S (2002) Removal of Ni(II) from aqueous solution by adsorption onto hazelnut shell activated carbon: Equilibrium studies. Bioresour Technol 84: 291-293.

7. Revathi M (2005) Removal of nickel ions from industrial plating effluents using activated alumina as adsorbent. J Environ Eng, 47: 1.

8. Pradhan S, Shukla SS, Dorris KL (2005) Removal of nickel from aqueous solutions using crab shells. J Hazard Mater 125: 201-204.

9. Bulut $Y$, Tez $Z$ (2007) Removal of heavy metals from aqueous solution by sawdust adsorption. J Hazard Mater 19: 160-166.

10. Rafatullah M, Sulaiman O, Hashim R, Ahmad A (2009) Adsorption of copper(II) chromium(III), nickel(II) and lead(II) ions from aqueous solutions by meranti sawdust. J Hazard Mater 170: 969-977.

11. Ramezankhani R, Sharifi AAM, Sadatipour T, Abdolahzadeh R (2008) A mathematical model to predict nickel concentration in karaj river sediments. Iran J Environ Health Sci and Eng 5: 91-94.

12. Rao M, Parwate AV, Bhole AG (2002) Removal of $\mathrm{Cr}^{6+}$ and $\mathrm{Ni}^{2+}$ from aqueous solution using bagasse and fly ash. Waste Management 22: 821-830.

13. Viraraghvan T, Drohamraju M (1993) Removal of copper, nickel and zinc from wastewater by adsorption using peat. Journal of Environmental Science and Heal 28: 1261-1276.

14. Dimitrova SV (1996) Metal sorption on blast-furnace slag. Water Res 30: 228-232.

15. Maranon E, Sastre H (1991) Heavy metal removal in packed beds using apple wastes. Bioresour Technol 38: 39-43.

16. Marshall WE, Champagne ET Evans WJ (1995) The use of rice milling by products to remove metal ions from solution. Journal of Environmental Science and Health 9: 1977-1992.
17. Periasamy K, Namasivayam C (1995) Removal of nickel(II) from aqueous solution and nickel electroplating industry wastewater using an agricultural waste: Peanut hulls. Waste Management 15: 63-68.

18. Meena AK (2003) Adsorption of $\mathrm{Ni}(\mathrm{II})$ and $\mathrm{Zn}$ (II) from aqueous solution by chemically treated activated carbon. National Conference on Carbon (IndoCarbon 2003) National Institute of Ayurvedic Pharmaceutical Research Kanpur $131-141$.

9. Shukla A, Zhang YH, Dubey P, Margrave JL, Shukla SS (2002) The role of sawdust in the removal of unwanted materials from water. $\mathrm{J}$ Hazard Mater 95 137-152.

20. Sikkema FD, Comellas-Aragonès M, Fokkink RG, Verduin BJ, Cornelissen JJ (2007) Monodisperse polymer-virus hybrid nanoparticles. Organic and Biomolecular Chemistry 5: 54-57.

21. Alhaji NMI, Tajun KM, Begum M (2015) Optimization and Kinetic Study for the Removal of Chromium (VI) lons by Acid Treated Sawdust -Chitosan Composite Beads. International Research Journal of Pure \& Applied Chemistry 5: 160-176.

22. Demirbas E, Kobya M, Oncel S, Sencan S (2002) Removal of Ni (II) from aqueous solution by adsorption onto hazelnut shell activated carbon: equilibrium studies. Bioresour Technol 84: 291-293.

23. Vinodhini V, Das N (2010) Relevant approach to assess the performance of sawdust as adsorbent of chromium( $\mathrm{VI})$ ions from aqueous solutions. Int $\mathrm{J}$ Environ Sci Tech Winter 7: 85-92.

24. Rao M, Parwate AV, Bhole AG (2002) Removal of $\mathrm{Cr}^{6+}$ and $\mathrm{Ni}^{2+}$ from aqueous solution using bagasse and fly ash. Waste Management 22: 821-830.

25. Saadi Z, Saadi R, Fazaeli R (2013) Fixed-bed adsorption dynamics of $\mathrm{Pb}$ (II) adsorption from aqueous solution using nanostructured $\mathrm{Y}$-alumina. J Nanostruct Chem 3: 48-55.

26. Karthikeyan T, Rajagopal S, Miranda LR (2005) Chromium(VI) adsorption from aqueous solution by Hevea Brasilinesis sawdust activated carbon. J Hazard Mater 124: 192-199.

27. Cestari AR, Vieira EFS, Tavares AMG, Bruns RE (2008) The removal of indigo caramine dye from aqueous solutions using cross-linked chitosan-Evaluation of adsorption thermodynamics using a full factorial design $\mathrm{J}$ Hazard Mater 153 566-574.

28. Dada AO, Olalekan AP, Olatunya AM, Langmuir O, Freundlich (2012) Temkin and Dubinin-Radushkevich Isotherms Studies of Equilibrium Sorption of $\mathrm{Zn}^{2+}$ Unto Phosphoric Acid Modified Rice Husk. Journal of Applied Chemistry 3 38-45.

29. Rafatullah M, Sulaiman O, Hashim R, Ahmed A (2010) Adsorption of Copper(II) onto different adsorbents. J Dispers Sci Technol 31: 918-930.

30. Olayinka OK, Oyedeji OA, Oyeyiola OA (2009) Removal of Cr\&Ni ions from aq. sol. by adsorption on modified coconut husk. African J Enviorn Sci Technol 3: 286-293.

31. Yuh-Shan HO (2004) Selection of optimum sorption isotherm. Carbon 42: 2115-2116.

32. Chatterjee S, Lee DS, Lee MW, Woo SH (2009) Enhanced adsorption of Congo red from aqueous solutions by chitosan hydrogel beads impregnated with cetyl trimethylammonium bromide. Bioresour Technol 100: 2803-2809.

33. Annadurai G, Ling LY, Lee JF (2008) Adsorption of reactive dye from an aqueous solution by chitosan: isotherms, kinetic and thermodynamic analysis. J Harzard Mater 152: 337-346.

34. Weber WJ, Morris JC (1963) Kinetics of adsorption on carbon solution. J Sanitary Eng Div Am Soc Civ Eng 89: 31-59. 